\title{
PENGARUH MODUL BERBASIS KONSTRUKTIVIS TERHADAP KEMANDIRIAN BELAJAR MAHASISWA PADA MATA KULIAH FISIKA KUANTUM
}

\author{
Nurhayati \\ Prodi Pend. Fisika, Fakultas PMIPA \& Tek, IKIP PGRI Pontianak, Jalan \\ Ampera No.88 Pontianak \\ e-mail: nurhayatideli@gmail.com
}

\begin{abstract}
Abstrak
Penelitian ini bertujuan untuk mengetahui pengaruh penggunaan modul berbasis konstruktivis terhadap kemandirian belajar mahasiswa pada mata kuliah fisika kuantum dan respon mahasiswa terhadap penggunaan modul berbasis konstruktivis. Metode penelitian yang digunakan adalah metode eksperimen. Populasi adalah seluruh mahasiswa pendidikan fisika semester enam IKIP PGRI Pontianak tahun akademik 2014-2015, sejumlah tiga kelas. Sampel diambil dengan teknik cluster random sampling sejumlah dua kelas. Satu kelas eksperimen menggunakan modul konstruktivis dan satu kelas eksperimen menggunakan modul konvensional. Data kemandirian belajar dan respon mahasiswa diukur menggunakan teknik non-tes dengan alat ukur angket. Uji hipotesis menggunakan uji Kruskal Wallis yang terdapat pada program SPSS. Berdasarkan hasil analisis data dapat disimpulkan bahwa: (1) tidak terdapat pengaruh penggunaan modul berbasis konstruktivis terhadap kemandirian belajar mahasiswa, (2) respon mahasiswa terhadap penggunaan modul berbasis konstruktivis adalah positif.
\end{abstract}

Kata Kunci : Modul, konstruktivis, kemandirian belajar

\section{PENDAHULUAN}

Mata kuliah fisika kuantum adalah salah satu mata kuliah yang wajib ditempuh oleh mahasiswa program studi pendidika fisika IKIP PGRI Pontianak. Tujuan dalam mata kuliah fisika kuantum bagi mahasiswa pendidikan fisika adalah memiliki kemampuan menerapkan konsepkonsep dasar fisika kuantum pada persoalan-persoalan fisika mikro sederhana serta dapat mengaplikasikannya sesuai dengan perkembangan sains dan teknologi. Materi fisika kuantum yang bersifat abstrak dan memuat banyak konsep matematika membuat mahasiswa merasa kesulitan dalam memahami materi tersebut. Terbukti, dalam dua tahun akademik berturutan (Gambar 1), rerata hasil belajar mahasiswa pada mata kuliah ini berkisar antara 2,30 sampai dengan 2,36 pada skala lima.

Berdasarkan Gambar 1, diketahui bahwa setiap tahun akademik hanya terdapat kurang dari 50\% mahasiswa yang berhasil lulus dengan nilai minimal berkategori B. Rendahnya hasil belajar mahasiswa tersebut merupakan indikator rendahnya penguasaan mereka terhadap konsep-konsep mata kuliah fisika kuantum. Jika dibiarkan, hal ini dikhawatirkan akan sangat mempengaruhi kualitas penguasaan mahasiswa dalam materi mata kuliah fisika lanjut, yang memprasyaratkan penguasaan konsep mata kuliah fisika kuantum yang dikenal sebagai ilmu dasar bagi penelaahan gejala dan sifat berbagai sistem mikroskopik (Krane, 1992; Tjia, 1999). 


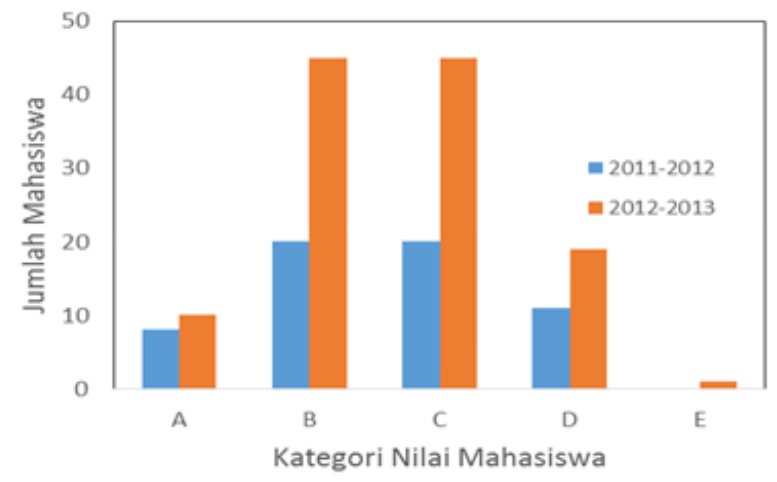

Gambar 1. Distribusi Nilai Mahasiswa Berdasarkan Tahun Akademik

Berdasarkan hasil observasi yang dilakukan, diperoleh informasi bahwa rendahnya hasil belajar mahasiswa pada mata kuliah fisika kuantum disebabkan oleh beberapa faktor. Diantaranya (1) kebanyakan materi fisika kuantum yang bersifat abstrak, (2) kurangnya kemampuan matematik dasar yang dimiliki oleh mahasiswa, (3) proses pembelajaran yang masih cenderung ceramah, (4) sistem evaluasi, dosen hanya terpaku pada penilaian dari hasil Ujian Tengah Semester (UTS), hasil Ujian Akhir Semester (UAS), dan nilai tugas, masing-masing dengan bobot sesuai dengan yang telah disepakati, dan (5) kemampuan mahasiswa dalam menyelesaikan soal-soal secara mandiri sangat kurang. Hal ini terlihat dari jumlah mahasiswa yang tidak mampu menjawab soal yang diberikan dalam latihan. Padahal, soal tersebut merupakan hasil modifikasi dari contoh soal yang telah diberikan penyelesaiannya.

Selain itu, wawancara yang dilakukan dengan beberapa mahasiswa program studi pendidikan fisika yang pernah mengikuti mata kuliah fisika kuantum hasilnya menunjukkan bahwa hampir $\quad 70 \%$ mahasiswa kurang menyenangi dan takut untuk mengikuti mata kuliah ini. Kebanyakan mereka menganggap bahwa materi fisika kuantum terlalu banyak rumus dan memerlukan kemampuan abstrak yang tinggi. Mereka mengatakan bahwa mereka dapat mengerti dan memahami materi perkuliahan yang disajikan dosen, tetapi setelah dihadapkan pada permasalahan yang berkenaan dengan materi fisika kuantum, mereka tidak mampu memecahkan masalah yang dihadapi tersebut. Hal ini menunjukkan bahwa hasil belajar mahasiswa pada mata kuliah ini tidak bersifat tahan lama dan berkelanjutan. Akibatnya, mahasiswa tidak mampu menerapkan konsep-konsep yang diperolehnya dalam situasi baru, sehingga pemahaman konsep-konsep materi pada mata kuliah fisika lanjut menjadi kurang yang berimplikasi pula pada rendahnya hasil belajar yang dicapai mahasiswa.

Oleh karena itu diperlukan suatu media yang dapat digunakan mahasiswa untuk mengkonstruksi konsep-konsep yang dipelajari. Satu diantaranya adalah modul yang berbasis konstruktivis. Modul merupakan paket belajar mandiri yang meliputi serangkaian pengalaman belajar yang direncanakan serta dirancang secara sistematis untuk membantu siswa mencapai tujuan belajar (Mulyasa 2004: 43). Menurut Cipto Utomo dan Kies Ruijter (dalam Suardana 2006: 5), "penerapan modul dalam pembelajaran sangat memberikan peluang yang baik bagi pebelajar pada usia dewasa dan dapat mengatasi perbedaan terutama dalam kecepatan belajar bagi mahasiswa. Melalui modul berbasis konstruktivis, pengetahuan mahasiswa tentang materi fisika 
kuantum dibangun secara bertahap dari hasil yang diperoleh melalui konteks yang terbatas. Pengetahuan yang diperoleh tidak hanya seperangkat fakta, konsep, atau kaidah yang siap diambil dan diingat belaka, melainkan mahasiswa harus mengkonstruksi sendiri pengetahuan tersebut barulah kemudian memberi makna melalui pengetahuan yang nyata.

Berdasarkan latar belakang di atas, maka fokus permasalahan dalam penelitian ini yaitu (1) Apakah terdapat pengaruh penggunaan modul berbasis konstruktivis terhadap kemandirian belajar mahasiswa?, (2) Bagaimana respon mahasiswa terhadap penggunaan modul berbasis konstruktivis pada mata kuliah fisika kuantum?.

\section{METODE PENELITIAN}

Metode penelitian ini adalah metode eksperimen dengan bentuk eksperimen semu. Subjek dalam penelitian ini adalah mahasiswa semester VI Program Studi Pendidikan Fisika IKIP PGRI Pontianak yang sedang mengikuti perkuliahan fisika kuantum sebanyak dua kelas. Jumlah subjek yang dilibatkan dalam penelitian ini adalah 60 orang yang terdiri atas 30 orang kelas eksperimen dan 30 orang kelas kontrol. Hasil uji kesetaraan melalui uji $\mathrm{t}$ independent sampel menunjukkan keadaan awal kedua kelas sampel tidak berbeda (Budiyono, 2009: 105).

Data penelitian dalam penelitian dikumpulkan menggunakan teknik nontes. Alat pengumpul data yaitu angket kemandirian belajar dan respon mahasiswa dengan skala Likert. Sebelum instrumen digunakan guna untuk mengambil data, instrumen diujicobakan untuk mengetahui tingkat uji validitas dan reliabilitas (Surapranata, 2009: 10). Pernyataan angket yang digunakan dalam penelitian memiliki kriteria valid dengan reliabilitas yang tinggi.

Teknik analisis data kemandirian belajar diawali dengan uji normalitas dan homogenitas data. Uji normalitas bertujuan untuk mengetahui sampel yang diambil berasal dari populasi yang berdistribusi normal atau tidak normal. Uji ini dilakukan dengan menggunakan program SPSS versi 16 dengan pilihan tes uji yang digunakan yaitu Kolmogorov-Smirnov. Sedangkan uji homogenitas data dilakukan untuk mengetahui suatu sampel berasal dari populasi yang homogen atau tidak homogen. Uji homogenitas menggunakan uji Levene yang juga diolah menggunakan progran SPSS versi 16. Uji prasyarat analisis menunjukkan bahwa sebagian besar data penelitian tidak berdistribusi normal dan homogen, sehingga pengujian hipotesis penelitian ini menggunakan statistik non parametrik yaitu uji Kruskal Wallis. Pengujian hipotesis juga dilakukan dengan bantuan program SPSS (Sulaiman, 2005: 29).

\section{HASIL DAN PEMBAHASAN}

Penelitian ini bertujuan untuk mengetahui pengaruh penggunaan modul berbasis konstruktivis terhadap kemandirian belajar mahasiswa dan respon mahasiswa terhadap penggunaan modul berbasis konstruktivis.

Uji prasyarat analisis meliputi uji normalitas dan uji homogenitas data. Rangkuman uji prasyarat analisis disajikan pada Tabel 1 dan Tabel 2.

Tabel 1. Hasil Uji Normalitas Data Kemandirian Belajar Mahasiswa

\begin{tabular}{ccccc}
\hline \multirow{2}{*}{ Jenis Data } & \multirow{2}{*}{ Kelas } & \multicolumn{3}{c}{ Kolmogorov-Smirnov } \\
\cline { 3 - 5 } & & Statistic & df & Sig. \\
\hline Kemandirian Belajar & Eksperimen & 0,115 & 25 & 0,200 \\
\hline
\end{tabular}


Berdasarkan Tabel 1, tampak bahwa nilai signifikansi kemandirian belajar mahasiswa berdasarkan modul pembelajaran baik modul konstruktivis maupun modul konvensional berturutturut adalah 0,200 dan 0,200. Hal ini menunjukkan bahwa data kemandirian belajar mahasiswa ditinjau dari modul pembelajaran berasal dari populasi yang berdistribusi normal karena nilai signifikansinya lebih besar dari 0,05.

\section{Tabel 2. Hasil Uji Homogenitas Data Kemandirian Belajar Mahasiswa}

\begin{tabular}{lcccc}
\hline \multirow{2}{*}{ Data } & \multicolumn{4}{c}{ Levene Test } \\
\cline { 2 - 5 } & Statistic & $\mathbf{d f}_{\mathbf{1}}$ & $\mathbf{d f}_{\mathbf{2}}$ & Sig. \\
\hline Kemandirian Belajar & 4,473 & 1 & 48 & 0,040 \\
\hline
\end{tabular}

Berdasarkan Tabel 2, terlihat bahwa nilai signifikansi yang diperoleh dengan Levene's test untuk kemandirian belajar mahasiswa lebih kecil dari 0,05. Hal ini menunjukkan bahwa data kemandirian belajar mahasiswa tidak berasal dari populasi yang homogen. Karena data penelitian berdistribusi normal dan tidak homogen maka pengujian hipotesis penelitian dilakukan dengan statistik non-parametrik.

Hipotesis nil (Ho) dalam penelitian ini yaitu tidak terdapat pengaruh penggunaan modul berbasis konstruktivis terhadap penguasaan konsep mahasiswa. Rangkuman hasil uji hipotesis penelitian menggunakan uji Kruskal Wallis dapat dilihat pada Tabel 3 berikut.

Tabel 3. Hasil Uji Hipotesis

\begin{tabular}{lccc}
\hline \multirow{2}{*}{ Dependent Variable } & \multicolumn{3}{c}{ Kruskal Wallis } \\
\cline { 2 - 4 } & Chi-Square & df & Sig. \\
\hline Kemandirian Belajar & 1,060 & 1 & 0,303 \\
\hline
\end{tabular}

Berdasarkan Tabel 3, diketahui bahwa nilai signifikansi lebih besar dari 0,05 sehingga dapat disimpulkan bahwa Ho diterima dan Ha ditolak. Hal ini berarti tidak terdapat pengaruh penggunaan modul berbasis konstruktivis terhadap penguasaan konsep mahasiswa.

Penggunaan modul fisika kuantum berbasis kontruktivis pada mahasiswa semester VI program studi pendidikan fisika tidak berpengaruh terhadap kemandirian belajar mahasiswa dikarenakan pada proses pembelajaran, baik di kelas eksperimen maupun di kelas kontrol mendapatkan perlakuan atau bimbingan yang sama oleh dosen. Dosen belum sepenuhnya memberikan kebebasan kepada mahasiswa untuk belajar sendiri dan 22 mencari pemecahan masalah sendiri sehingga mahasiswa menjadi kurang memiliki rasa tanggungjawab terhadap apa yang dikerjakannya dan menyebabkan kurangnya rasa kepercayaan dalam dirinya.

Belajar mandiri adalah kegiatan belajar aktif yang didorong oleh motif untuk menguasai suatu kompetensi guna mengatasi masalah dan dibangun dengan bekal pengetahuan atau kompetensi yang dimiliki (Mujiman dalam Sunarto, 2008). Selain itu, konsep belajar mandiri menurut Malcolm (dalam Sunarto, 2008) adalah (1) iklim belajar seyogyanya merupakan sesuatu yang membuat mahasiswa merasa diterima, dihargai, dan didukung yakni satu semangat mutualitas antara dosen dan mahasiswa, (2) penguatanNurhayati 
penguatan seyogyanya diletakkan pada keterlibatan mahasiswa dalam proses diagnosis diri terhadap kebutuhan belajar, (3) mahasiswa seharusnya dilibatkan dalam proses belajarnya karena dosen berperan sebagai pemandu dan sumber materi, (4) proses pembelajaran adalah satu tanggungjawab bersama antara mahasiswa dan dosen karena dosen menjadi sumber dan katalisator bukan sebagai seorang pengajar. Dan (5) mahasiswa seharusnya terpanggil untuk mengevaluasi diri dengan bantuan dosen.

Seyogyanya mahasiswa yang mempunyai kemandirian belajar adalah mahasiswa yang secara aktif berpartisipasi dalam menentukan apa yang akan dipelajarinya dan bagaimana belajarnya. Mahasiswa tidak tergantung pada pengarahan dosen yang terus menerus tetapi mahasiswa juga mempunyai kreativitas dan inisiatif sendiri, serta mampu untuk bekerja sendiri dengan merujuk pada bimbingan yang diperolehnya.

Oleh karena itu, peran dosen dalam proses pembelajaran sebaiknya hanya sebagai fasilitator yang harus bertindak aktif memotivasi mahasiswa agar aktif dalam mengkonstruksi pengetahuannya. Dosen juga berperan sebagai manajer pembelajaran yang mengelola perbelajaran agar menjadi pembelajaran yang menyenangkan, aktif dan bermakna.

Respon mahasiswa terhadap modul berbasis konstruktivis diperoleh dari angket respon yang diberikan kepada mahasiswa pada akhir pembelajaran. Hasil angket menunjukkan bahwa secara keseluruhan mahasiswa memiliki sikap positif terhadap perkuliahan fisika kuantum melalui penggunaan modul berbasis konstruktivis. Secara umum tangapan mahasiswa diantaranya (1) mahasiswa merasa jelas tujuan belajarnya, karena di dalam modul disajikan kompetensi dan tujuan yang akan dicapai, (2) modul disajikan dengan pertanyaan-pertanyaan yang dapat mendorong mahasiswa untuk menemukan penjabaran persamaan yang dicari, (3) modul dilengkapi dengan soal-soal latihan, sebagai uji kemampuan mahasiswa dalam penguasaan konsep yang telah dibelajarkan.

\section{SIMPULAN}

Berdasarkan penelitian yang telah dilakukan, dapat disimpulkan bahwa (a) tidak terdapat pengaruh penggunaan modul berbasis konstruktivis terhadap penguasaan konsep mahasiswa, (b) respon mahasiswa terhadap modul berbasis konstruktivis yang diterapkan adalah positif.

\section{UCAPAN TERIMA KASIH}

Penelitian ini dibiayai oleh DIKTI sehingga peneliti mengucapkan terima kasih yang sebesar-besarnya kepada DIKTI atas bantuan yang diberikan. Selain itu peneliti juga mengucapkan terima kasih kepada IKIP PGRI Pontianak yang telah memberikan dukungan sehingga penelitian ini bisa terlaksana.

\section{DAFTAR PUSTAKA}

Budiyono. 2009. Statistik untuk Penelitian Edisi Ke-2. Surakarta: Universitas Sebelas maret Press.

Krane, K. 1992. Modern Physics. Singapore, John Wiley \&Sonc, Inc.

Mulyasa, E. 2004. Kurikulum Berbasis Kompetensi: Konsep, Karakteristik, dan Implementasi. Bandung: Remaja Rosdakarya.

Suardana. 2006. Pembelajaran Modul Yang Berwawasan Konstruktivis: Upaya Meningkatkan Kemampuan Belajar Mandiri Dan Hasil Belajar Mahasiswa Pada Mata Kuliah Fisika 
Kuantum. Jurnal Pendidikan dan Pengajaran IKIP Negeri Singaraja No.2 Tahun XXXIX April.

Sulaiman, W. 2005. Statistik NonParametrik: Contoh kasus dan Pemecahannya dengan SPSS. Yogjakarta: Andi Publisher.

Sunarto. 2008. Kemandirian Belajar. (Online)

(http://banjarnegarambs.wordpress.c om/2008/09/10/kemandirian-belajarsiswa/. Internet, diakses 1 Juni 2015.

Surapranata, S. 2009. Analisis, Validitas, Reliabilitas dan Intepretasi Hasil Tes-Implementasi Kurikulum 2004. Bandung: Remaja Rosdakarya. 